\title{
Steel Micro-alloying with Boron: A Perspective Direction to Reduce the Consumption of Manganese Ferroalloys
}

\author{
A.A. Babenko1, V.I. Zhuchkov¹, L.A. Smirnov¹, A.A. Akberdin², and \\ A.G. Upolovnikova ${ }^{1}$ \\ ${ }^{1}$ IMET UB RAS, Ekaterinburg, Russia \\ ${ }^{2}$ Abishev Chemical-Metallurgical Institute, Karaganda, R. Kazakhstan
}

\section{Abstract}

Manganese ferroalloys occupy a strategically important place in the total production of ferroalloys, since no steel grade can be made without the manganese addition. Today, the metallurgical complex of Russia is fully dependent on imports of manganese products (raw ore and ferroalloys), so special attention should be paid to the issues of more rational use of manganese. In particular, one should more widely use the

Corresponding Author:

A.A. Babenko

babenko251@gmail.com

Received: 5 February 2019

Accepted: 6 March 2019

Published: 17 March 2019

Publishing services provided by Knowledge E

(c) A.A. Babenko et al. This article is distributed under the terms of the Creative Commons Attribution License, which permits unrestricted use and redistribution provided that the original author and source are credited.

Selection and Peer-review under the responsibility of the NIOKR-2018 Conference Committee. methods of direct micro-alloying of steel with manganese in steel-smelting units and ladle-furnaces unit (LFU) and expand the range of high-strength steel with reduced manganese content, micro-alloyed with high-performance elements. Among the micro-alloying elements, a special place is occupied by boron. Its introduction into the metal in the amount of $0.001-0.005 \%$ makes it possible to save expensive and scarce alloying elements, in particular manganese, and to provide an increase in the strength of steel without reducing ductility. The results of the studies of the physicochemical properties of slags of the system $\mathrm{CaO}-\mathrm{SiO}_{2}-\mathrm{B}_{2} \mathrm{O}_{3}-\mathrm{Al}_{2} \mathrm{O}_{3}-\mathrm{MgO}$ had formed the basis for the technology development for the formation of basic boron-containing slags, that implementation at the LFU in the converter shop of JSC "ArcelorMittal Temirtau" provided the smelting of boron-containing steel economically doped with manganese with low-content of sulfur and high strength and plastic properties. The developed technology provided, depending on the steel grade, a boron content of $0.001-0.008 \%$ by weight, low concentration of sulfur in the metal, not more than $0.004-0.014 \%$ by weight, and reducing the manganese ferroalloys consumption from 0.5 to $1.4 \mathrm{~kg} / \mathrm{ton}$ of steel.

Keywords: pipe steel, manganese, sulfur, boron, mechanical properties, structure

\section{Introduction}

Both abroad and in our country steelmaking is characterized by ups and downs. Despite the observed fluctuations in the steel production, there is a general trend in increasing the volume of smelting. At the same time, the volume of steel production determines 
steelmaking and produced steel grades. Manganese ferroalloys occupy a strategically important place in the total production of ferroalloys, since without the addition of manganese, no single grade of steel can be smelted [1-4]. For example, the need for manganese ferroalloys with an annual steel production in the amount of 70-80 million tons is $0.5-0.6$ million tons or about $7.5 \mathrm{~kg} /$ ton of steel $[1,2,5]$.

During the existence of the USSR, a powerful mining and ferroalloy industries was created, which fully provided the steel industry of the country with manganese ferroalloys. That production was concentrated in the Ukrainian and Georgian republics. After the collapse of the USSR, the metallurgical complex of Russia became completely dependent on imports of manganese products (raw ore and ferroalloys) from Ukraine, Kazakhstan and a number of foreign countries. Reserves of proven domestic manganese ores deposits can't yet fully meet the domestic demand for this metal. In the foreseeable future, we will be able to switch to self-sufficiency in manganese ores, with substantial investments in geological exploration, research and the creation of mining and processing enterprises[4].

Considering the fact that own manganese in the required quantities will not appear in Russia soon enough, special attention should be paid to the issues of its more rational use. In particular, methods of direct micro-alloying of steel with manganese in steelmaking aggregates and LFU should be more widely used, and the range of high-strength steel with reduced manganese content micro-alloyed with high-performance elements should be expanded[3, 6-11].

Among the micro-alloying elements, a special place is occupied by boron, that introduction into the metal in amounts of $0.001-0.005 \%$ makes it possible to save expensive and scarce alloying elements, in particular manganese, and to ensure an increase in the strength of steel without reducing ductility [6, 9-11].

Microalloying of steel with boron is usually carried out due to additives of boroncontaining ferroalloys, that increases the steel cost. One way to solve the problem of micro-alloying steel with boron (with minimal costs) can be the direct micro-alloying by reducing boron from an oxide system of $[10,12]$.

Fundamental viscosity researches of slags of the system $\mathrm{CaO}-\mathrm{SiO}_{2}-\mathrm{B}_{2} \mathrm{O}_{3}-\mathrm{Al}_{2} \mathrm{O}_{3}-$ $\mathrm{MgO}$ and the equilibrium interfacial distribution of boron and sulfur between slag and metal, carried out by scientists of IMET UB RAS, [10, 13, 14], formed the basis for the development of the basic boron-containing slag formation technology. Its implementation in the converter shop of JSC "ArcelorMittal Temirtau" provided the smelting of economically alloyed with manganese boron-containing steel with low sulfur content and high strength and plastic properties [10]. 
Formation of basic boron-containing slags was carried out using the LFU, by loading lime into a casting ladle, boron-containing material - colemanite (containing 39-41\% $\mathrm{B}_{2} \mathrm{O}_{3}, 26-28 \% \mathrm{CaO}$, not more than $5 \% \mathrm{SiO}_{2}$ and $3 \% \mathrm{MgO}$ ) and pyramidal aluminum for deoxidation of slag and boron recovery [10-15](The work involved Vituschenko M.F., Dobromilov A.A., Savrasov V.I., Kutdusov H.J., Kim A.A.). Technological and technicaleconomic indicators of experimental and comparative heats are given in Table 1. As comparative, current production melts with the use of fluorspar or alumina-containing slag during the formation of slags were used.

TABLE 1: Some technological and technical - economic indicators of experimental and comparative heats.

\begin{tabular}{|c|}
\hline Indicators \\
\hline $\begin{array}{l}\text { Materials using on } \\
\text { LFU, kg Lime }\end{array}$ \\
\hline Colemanite \\
\hline Fluorspar \\
\hline $\mathrm{Al}_{2} \mathrm{O}_{3}$ - slag \\
\hline Al wire \\
\hline Al pyramidal \\
\hline $\begin{array}{l}\text { Processing time } \\
\text { using LFU, min }\end{array}$ \\
\hline$[\mathrm{B}] . \%$ мас \\
\hline$[\mathrm{S}]_{\text {start }}$ LFU,\%мac. \\
\hline$[\mathrm{S}]_{\text {end }} \mathrm{LFU} \% \mathrm{Mac}$. \\
\hline$\triangle \mathrm{S}$ LFU,\%отн. \\
\hline
\end{tabular}

\begin{tabular}{|c|c|}
\hline \multicolumn{2}{|c|}{$\mathbf{0 8 k p}$} \\
\hline Exp. & Comparat. \\
\hline 1394 & 800 \\
\hline 110 & 0 \\
\hline 0 & 60 \\
\hline 0 & 0 \\
\hline 148 & 240 \\
\hline 134 & 80 \\
\hline 68,4 & 71,0 \\
\hline 0,001 & 0 \\
\hline 0,017 & 0,013 \\
\hline 0,014 & 0,012 \\
\hline 17,6 & 7,7 \\
\hline
\end{tabular}

\begin{tabular}{|c|c|}
\hline \multicolumn{2}{|c|}{ 09G2 } \\
\hline Exp. \\
\hline 1386 \\
\hline 144 \\
\hline 0 \\
\hline 0 \\
\hline 44 \\
\hline 147 \\
\hline 123,1 \\
\hline 0,004 \\
\hline 0,013 \\
\hline 0,010 \\
\hline 23,1 \\
\hline
\end{tabular}

09G2S

Comparat.

1280

0

0

200

112

160

104,0

0

0,017

0,013

23,5

\begin{tabular}{|c|c|}
\hline \multicolumn{2}{|c|}{ 17G1SU } \\
\hline Exp. & Comparat. \\
\hline 2140 & 2617 \\
\hline 258 & - \\
\hline- & - \\
\hline- & 530 \\
\hline 115 & 140 \\
\hline 373 & 381 \\
\hline 138 & 181 \\
\hline 0,008 & 0 \\
\hline 0,012 & 0,010 \\
\hline 0,004 & 0,003 \\
\hline 66,7 & 68,0 \\
\hline
\end{tabular}

The formation of basic boron-containing slags ensures the development of the process of direct micro-alloying of steel with boron due to its recovery from slag. With an average consumption of colemanite $144 \mathrm{~kg}$ per smelting and reducing agent (pyramidal aluminum) in the amount of $147 \mathrm{~kg}$ per smelting, microalloying with boron in the amount of $0.004 \%$ was noted. Reducing the consumption of colemanite to $110 \mathrm{~kg}$ for smelting does not provide for the consumption of pyramidal aluminum in the amount of $134 \mathrm{~kg}$ for smelting the boron content in steel above $0.001 \%$. The increased consumption of colemanite up to $258 \mathrm{~kg}$ for smelting, together with a high (373 kg for smelting) consumption of pyramidal aluminum, provides a higher boron content in steel, reaching on average $0.008 \%$. At the same time, the exposure of the metal under the main boron-containing slags is accompanied by a high degree of desulfurization $(\Delta S)$. So, in melts deoxidized only with aluminum (08KP), the degree of metal desulfurization reaches $17.6 \%$, that is almost 2.3 times higher than in the current production (Table 1). Deoxidation of steel with aluminum and silicon (09G2S) provides a high degree of metal desulfurization, reaching 
23.1\%. At the same time in the experimental metal the sulfur content is at the level of $0.010 \%$ versus $0.013 \%$ in the metal of the current production. Experimental melting of $17 G 1 S$ - $U$ pipe steel also maintains a high degree of metal desulfurization - $66.7 \%$. The average sulfur content in the metal reaches $0.004 \%$ with an average decrease of $477 \mathrm{~kg}$ per smelting lime consumption and a reduction in the steel processing time at the LFU by 43 minutes. The mechanical properties of experimental and comparative metal-roll samples of steel grades 08KP, 09G2S and 17G1S-U are given in Table 2.

TABLE 2: Mechanical properties of experimental and comparative samples of metal.
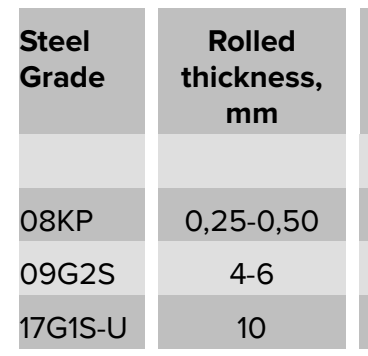

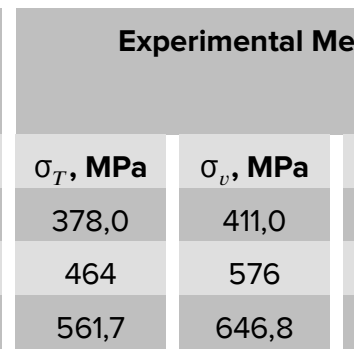

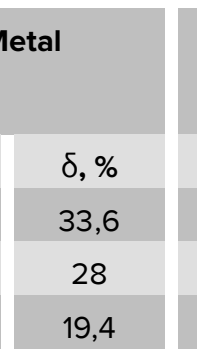

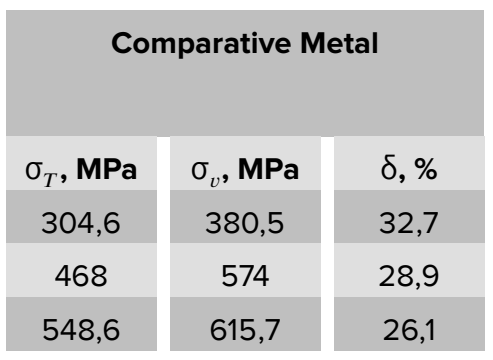

Rolling $0.25-0.50 \mathrm{~mm}$ thick from "boiling" steel, containing on average $0.001 \%$ of boron, is characterized by enhanced strength and plastic properties. The absolute values of the yield strength and temporary resistance on the experimental metal are 73.4 and 30.5 MPa higher than on the metal of the comparative melts. The magnitude of the relative elongation, which characterizes the plastic properties of rolled metal, reaches, on the average, 33.6 on the experimental metal versus $32.6 \%$ on the smelting of the comparative metal. The strength properties and plastic characteristics of low-alloyed metal of 09G2S grade, containing on the average $0.004 \%$ of boron, practically do not differ from the properties of metal-roll of comparative melts. Pipe steel grade 17G1S$\mathrm{U}$, containing on the average of $0.008 \%$ boron, is characterized by enhanced strength properties. The absolute values of the yield strength and temporary resistance on the experimental metal with a thickness of $10.0 \mathrm{~mm}$ are 13.1 and $31.1 \mathrm{MPa}$ are higher than on the smelting of the comparative metal. In this case, the plastic characteristics of rolled products meet the requirements of GOST.

As noted above, the microalloying of steel using boron makes it possible to save expensive alloying elements, providing high strength properties of rolled metal. Table 3 shows the experimental data characterizing the effect of low concentrations of manganese in boron micro-alloyed steel on the mechanical properties of rolled metal. The decrease in the content of manganese in $08 \mathrm{KP}$ steel by $0.05 \%$ practically did not affect the strength properties, while providing an increase on the average by $1.8 \%$ of the plastic performance of metal-roll $0.25-0.50 \mathrm{~mm}$ thick. At the same time, the specific consumption of manganese ferroalloys is reduced on the average by $0.5 \mathrm{~kg} / \mathrm{t}$ of steel. 
TABLE 3: Mechanical properties of metal-rolls of experimental heats depending on the content of manganese in steel.

\begin{tabular}{|c|c|c|c|c|c|c|c|c|c|c|c|}
\hline \multirow{2}{*}{$\begin{array}{l}\text { Steel } \\
\text { grade }\end{array}$} & \multicolumn{6}{|c|}{ Chemical composition of steel, \% } & \multirow{2}{*}{$\begin{array}{c}\text { Thick., } \\
\text { mm }\end{array}$} & \multirow{2}{*}{$\begin{array}{c}\sigma, \\
\text { МПа }\end{array}$} & \multirow{2}{*}{$\begin{array}{c}\sigma, \\
\text { МПа }\end{array}$} & \multirow[t]{2}{*}{$\delta, \%$} & \multirow{2}{*}{$\begin{array}{c}\text { Mn fer.- } \\
\text { all.cons., } \\
\text { kg/t }\end{array}$} \\
\hline & C & Mn & Si & $\mathbf{P}$ & $\mathbf{s}$ & B & & & & & \\
\hline 08KP & $\begin{array}{l}0,06 \\
0,05\end{array}$ & $\begin{array}{l}0,24 \\
0,19\end{array}$ & $\begin{array}{l}0,013 \\
0,010\end{array}$ & $\begin{array}{l}0,016 \\
0,014\end{array}$ & $\begin{array}{l}0,011 \\
0,016\end{array}$ & $\begin{array}{l}0,0024 \\
0,0030\end{array}$ & $0,25-0,50$ & $\begin{array}{l}377 \\
380\end{array}$ & $\begin{array}{l}415 \\
408\end{array}$ & $\begin{array}{l}32,5 \\
34,3\end{array}$ & $\begin{array}{l}2,8 \\
2,3\end{array}$ \\
\hline 09G2S & $\begin{array}{l}0,08 \\
0,07\end{array}$ & $\begin{array}{l}1,57 \\
1,42\end{array}$ & $\begin{array}{c}0,63 \\
0,65\end{array}$ & $\begin{array}{l}0,025 \\
0,020\end{array}$ & $\begin{array}{l}0,010 \\
0,009\end{array}$ & $\begin{array}{l}0,0048 \\
0,0030\end{array}$ & $4,0-6,0$ & $\begin{array}{r}429 \\
497\end{array}$ & $\begin{array}{l}551 \\
590\end{array}$ & $\begin{array}{l}29,5 \\
27,0\end{array}$ & $\begin{array}{l}22,2 \\
20,8\end{array}$ \\
\hline 17G1S-U & $\begin{array}{l}0,07 \\
0,06\end{array}$ & $\begin{array}{l}1,60 \\
1,40\end{array}$ & $\begin{array}{l}0,17 \\
0,17\end{array}$ & $\begin{array}{l}0,015 \\
0,014\end{array}$ & $\begin{array}{l}0,011 \\
0,003\end{array}$ & $\begin{array}{c}0,006 \\
0,006\end{array}$ & 10,0 & $\begin{array}{l}565 \\
585\end{array}$ & $\begin{array}{l}640 \\
650\end{array}$ & $\begin{array}{l}19,0 \\
20,0\end{array}$ & $\begin{array}{l}24,9 \\
24,1\end{array}$ \\
\hline
\end{tabular}

The positive effect of low manganese concentrations on the mechanical properties of rolled metal products was observed on steel 09G2S and 17G1S-U. It was found that boron microalloying of pipe steel provides the preferential formation of small non-metallic inclusions (not larger than 5 microns in size), which are represented by oxide and complex oxysulfide inclusions with the original oxide component based on aluminum-magnesium spinel with a small (not more than 1\%) content of sulfide inclusions on the spinel surface, the practical absence of isolated sulfide inclusions, the formation of a finely divided ferritic-bainite type structure and, as a result, high strength properties even at low contents of up to $1.4 \%$ manganese. The absolute values of the yield strength and temporary resistance of metal-roll pipe steel containing $1.4 \%$ manganese, $0.006 \%$ boron and $0.003 \%$ sulfur reach 585 (555-675) and 650 (625-825) MPa and provide, without heat treatment, the strength class $X 80$. In parentheses are the values of yield strength and tensile strength corresponding to the API Spect SL standard.

The fundamental results of the physicochemical properties study of the oxide system $\mathrm{CaO}-\mathrm{SiO}_{2}-\mathrm{B}_{2} \mathrm{O}_{3}-\mathrm{Al}_{2} \mathrm{O}_{3}-\mathrm{MgO}$ formed the basis for the development of the technology for the basic boron-containing slags formation on a LFU. The introduction of the developed technology, unparalleled in domestic and foreign practice, in the converter shop of JSC "ArcelorMittal Temirtau" ensured the production of low carbon steel of wide grades, economically doped with manganese, containing $0.001-0.004 \%$ sulfur, also reducing the consumption of manganese ferroalloys from 0.5 to $1.4 \mathrm{~kg} / \mathrm{t}$ of steel, the elimination of fluorspar additives and the achievement of high mechanical properties of the finished metal. 


\section{Funding}

The study was carried out with the help of the RFBR grant [project No. 16-08-00185].

\section{References}

[1] Zhuchkov, V.I., Smirnov, L.A., Zayko, V.P. et al. (2007). Technology of manganese ferroalloys. Part 1. High carbon ferromanganese. Ekaterinburg: UB RAS.

[2] Leontiev, L.I., Smirnov, L.A., Zhuchkov, V.I. et al. (2002). Production of steel and ferroalloys in the world. Electrometallurgy, № 2, pp. 2-9.

[3] Smirnov, L.A., Arzamastsev, E.I. and Babenko, A.A. (2003). The current state and prospects of providing domestic industry with manganese and chromium and rational ways of their use in steelmaking in Proceedings of the Seventh Congress of Steelmakers. Moscow: Chermetinformation.

[4] Bykhovsky, L.Z. and Tigunov, L.P. (2007). About the mineral resource base of metals for the ferroalloys production in Russia. Steel, № 1, pp. 42-45.

[5] Vorobiev, V.P. and Vozhennikov, S.G. (2009). Evaluation of the prospects for the use of imported highly basic manganese ores in Russia. Steel, № 7, pp. 38-40.

[6] Lyakishev, N.P., Pliner, Yu.L. and Lappo S.I. (1986). Steels and alloys with boron. Moscow: Metallurgy.

[7] Goldstein, Ya.E. and Mizin, V.G. (1986). Modification and microalloying of iron and steel. Moscow: Metallurgy.

[8] Pilyushenko, V.L. and Vikhlevshchuk, V.A. (2000). Scientific and technological foundations of microalloying of steel. Moscow: Metallurgy.

[9] Golubtsov, V.A. and Lunev, V.V. (2009). Steel modification for castings and ingots. Chelyabinsk-Zaporozhye: ZNSU.

[10] Babenko, A.A., Zhuchkov, V.I., Smirnov, L.A. et al. (2015). Research and development of an integrated technology for the production of low carbon steel with boron and low sulfur content. Steel, № 11, pp. 48-50.

[11] Kovalchuk, G.Z. and Yarmosh, V.N. (1988). Effect of boron microadditives on structural transformations and properties of low-manganese steels. Metallurgical Science and Heat Treatment of Metals, № 7, pp. 9-12.

[12] Krivko, E.M., Chub P.I. and Konovalov R.P. (1984). Rimmed steel microalloying with boron during its reduction from oxides in Casting steel into molds: scientific works proceedings. USSR MFM. Moscow: Metallurgy. 
[13] Babenko, A.A., Zhuchkov, V.I., Smirnov, L.A. et al. (2016). Using the method of simplex lattices for constructing composition-viscosity diagrams of slags of the system $\mathrm{CaO}$ $-\mathrm{SiO}_{2}-\mathrm{Al}_{2} \mathrm{O}_{3}-\mathrm{MgO}-\mathrm{B}_{2} \mathrm{O}_{3}$. Butlerov Communications, vol. 48, № 11, pp. 40-44.

[14] Upolovnikova, A.G. and Babenko, A.A. (2016). Thermodynamic modeling of boron recovery processes from boron-containing slags. Butlerov Communications, vol.48, № 10, pp. 114-118.

[15] Patent RU 2562849, publ. 10 September 2015. Authors: Babenko, A.A., Zhuchkov, V.I., Selivanov, E.N. et al. Slag mixture for steel processing in a ladle. 